\title{
Illegal Immigrant Parenting and Character Formation
}

\author{
Peter A Olsson* \\ Stowecroft Drive; Hampton, NH, USA
}

*Corresponding author: Peter Alan Olsson, 21 Stowecroft Drive; Hampton, NH 03842, USA, Tel: 6033139946; Email: polsson2@comcast.net

\author{
Opinion \\ Volume 5 Issue 1 \\ Received Date: April 01, 2021 \\ Published Date: April 08, 2021 \\ DOI: $10.23880 / \mathrm{mhrij}-16000140$
}

"The measure of a man's character is what he would do if he knew he never would be found out"

- Thomas Babington McCawley

"Weakness of attitude becomes weakness of character."

-Albert Einstein

\section{To Deport or Not to Deport? Perhaps Not the Question.}

During the presidential political campaigns a frequent question posed is, "What will we do with millions of illegal immigrants already in America?" The above is the wrong question. The more precise and important questions are:

$>$ What will good immigrant parents decide to do about their illegal situation and status?

$>$ What impact over time does a parent's living in the shadows of illegal, unethical, and criminal status have on their own character structure and by psychological influence, the character structure of their children?

$>$ Does the shadowy atmosphere of being an "illegal" cause denial of that reality?

$>$ Does denial or repression about being illegal often cause defiance, rebellion, and a false sense of entitlement?

$>$ Does being illegal often because a passive sense of psychological invisibility and submissiveness?

$>$ Is skipping to the head of the line to gain American citizenship and potential prosperity a violation of personal conscience?

$>$ Why did an illegal immigrant parent not fight for freedom, safety, and prosperity in their country of origin?

Let's discus personality, character, personality and character disorder as they relate to the parenting processes of illegal immigrant parents and the impact on the character of their children. Little has been written about the unconscious aspects of illegal immigrant's identities as parents.

\section{Definitions of Personality and Character}

For psychologists and psychiatrists, personality is the relatively persistent totality or complex array of behavioral and emotional characteristics that distinguishes an individual over time. Character is a core sector of personality. Good character implies adequate intelligence, a good sense of humor/playfulness, personal integrity, ethical consistency, social adaptability, and flexibility during adversity. It has survival value.

\section{Personality and Character Disorder}

In popular use, Character, implies more emphasis on ethical integrity. Character Disorder is manifested by an individual's chronic, habitual, repetitive and maladaptive patterns of behavior and emotional reactions. These patterns are relatively inflexible, limit the optimal use of potentialities, and often provoke responses that the person or group want to avoid. Traits of personality do not imply disorder. For example, vigilance, suspiciousness, and other paranoid personality traits, do not connote a paranoid personality disorder. In fact, they are essential and highly desirable for a policeman, FBI agent or combat soldier when they are on duty. An off-duty policeman with these persisting and pervasive traits in his personal life could well have a paranoid personality disorder. Neat, tidy, cleanly, and meticulous obsessive-compulsive traits, are highly valued for a surgeon or scrub nurse on-duty; but not while off-duty. Hysterical and emotionally evocative traits can gain success for an actor in Hollywood. In his or her personal life, they can cause chaos, divorce and plenty of publicity.

\section{Causes of Character Disorder}

Some personality traits are influenced by genes and inherited. However, "Nature/Nurture" issues arise from the fact that character and character disorder are formed over 


\section{Mental Health \& Human Resilience International Journal}

many years of personality development. Character forms in the context of family and social life in a community. Parental attitudes, parenting style, and values (or lack of them), are clearly shaping factors in personality formation. The quality of emotional, empathic, and nurturing connection between the child and caretakers, weave their effects into the developing personality over many years. The child unconsciously identifies with many parental traits or stoutly rebels against them.

\section{Parenting of Illegal Immigrants and the Results}

The conscious decision to illegally enter America has consequences. Often it leads to some real economic and educational advantages for illegal immigrants and their children. Education and a job in America afford dignity and the ability to send money back home to relatives in the country of origin. However, the clouds and shadow-side of the illegal entry decision lives on in the unconscious and preconscious mind. It festers in the conscience or lack of conscience formation in an illegal immigrant's mind. The implications of such an illegal immigrant parent's decision results in the intergenerational transmission of guilt and shame to the minds of their children and grandchildren. If there are no overt signs of this cultural class guilt and shame it is because of massive denial and reaction formation. Shameful and shameless behavior and hidden guilt about it can spawn acting-out behavior. Alcoholism, crime, reckless driving, and shameless predatory sexual behavior can result. Parents who are illegal immigrants have conscious, preconscious and unconscious impact on their children's minds, morals and character. A parent who is haunted or should be haunted by illegal behavior finds it hard to be an effective role-model and example of moral integrity for his child. The child can repress or suppress the hints about the shadowy family secret. The youth during adolescence can rebel and become defiant. The sense of entitlement and defiance can lead to acting-out and authority conflict. Without a strong parent with good moral character they push school authorities or the police into roles as stern father-figures. Earning a good college education is different than expecting it to be handed out as free stuff. Hard work to earn an education builds character as part of the process. "Free education" and other free stuff can promote future generations of sucking dependency upon government entitlement programs.

\section{Conclusion}

In conclusion, the shadowy family secret of an illegal immigrant family often gets transmitted over several generations unless or until the truth is faced and resolved. It is alarming to consider how seldom the illegal immigrant's parenting as it effects their children's identity formation is seriously discussed. Even highly successful children of illegal immigrants can understandably have normal pangs of conscience about the illegal behavior of their parents/ themselves. Paradoxically, the more personal integrity the child has, the more they will be haunted and hampered psychologically. The psychologically healthiest transform their guilt and shame into effective community service, often in the military or health care fields.

"Truth heals the pain which it evokes"

-Goethe

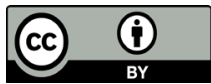

